\title{
Identification and characterization of alternative exon usage linked glioblastoma multiforme survival
}

\author{
Ahmed Sadeque ${ }^{1}$, Nicola VL Serão ${ }^{1}$, Bruce R Southey ${ }^{1}$, Kristin R Delfino ${ }^{1}$ and Sandra L Rodriguez-Zas ${ }^{1,2,3^{*}}$
}

\begin{abstract}
Background: Alternative exon usage (AEU) is an important component of gene regulation. Exon expression platforms allow the detection of associations between AEU and phenotypes such as cancer. Numerous studies have identified associations between gene expression and the brain cancer glioblastoma multiforme (GBM). The few consistent gene expression biomarkers of GBM that have been reported may be due to the limited consideration of AEU and the analytical approaches used. The objectives of this study were to develop a model that accounts for the variations in expression present between the exons within a gene and to identify AEU biomarkers of GBM survival.

Methods: The expression of exons corresponding to 25,403 genes was related to the survival of 250 individuals diagnosed with GBM in a training data set. Genes exhibiting AEU in the training data set were confirmed in an independent validation data set of 78 patients. A hierarchical mixed model that allows the consideration of covariation between exons within a gene and of the effect of the epidemiological characteristics of the patients was developed to identify associations between exon expression and patient survival. This general model describes all three possible scenarios: multi-exon genes with and without AEU, and single-exon genes.

Results: AEU associated with GBM survival was identified on 2477 genes (P-value < 5.0E-04 or FDR-adjusted P-value $<0.05$ ). G-protein coupled receptor 98 (Gpr98) and epidermal growth factor (Egf) were among the genes exhibiting AEU with 30 and 9 exons associated with GBM survival, respectively. Pathways enriched among the AEU genes included focal adhesion, ECM-receptor interaction, ABC transporters and pathways in cancer. In addition, 24 multi-exon genes without AEU and 8 single-exon genes were associated with GBM survival (FDR-adjusted P-value < 0.05).
\end{abstract}

Conclusions: The inferred patterns of AEU were consistent with in silico AS models. The hierarchical model used offered a flexible and simple way to interpret and identify associations between survival that accommodates multi-exon genes with or without AEU and single exon genes. Our results indicate that differential expression of AEU could be used as biomarker for GBM and potentially other cancers.

Keywords: Alternative Splicing (AS), Alternative Exon Usage (AEU), Glioblastoma Multiforme (GBM), Hierarchical model

\footnotetext{
* Correspondence: rodrgzzs@illinois.edu

${ }^{1}$ Department of Animal Sciences, University of Illinois Urbana-Champaign,

Urbana, IL, USA

${ }^{2}$ Department of Statistics, University of Illinois Urbana-Champaign, Urbana, IL,

USA

Full list of author information is available at the end of the article
} 


\section{Background}

Alternative splicing (AS) is characterized by the formation of different mRNA isoforms as a result of including or excluding different exonic or intronic segments. This process is responsible for generating protein diversity from a finite number of genes [1-3]. Alternative splicing can be divided into three broad categories; intron retention, cryptic splice-site usage, and alternative exon usage (AEU) or exon skipping. Alternative exon usage includes cassette exons, which are discrete exons that can be independently included or excluded, and mutually exclusive splicing, which involves the selection of one from a group of exon variants [2]. Approximately $75 \%$ of multiexon genes exhibit AS in humans [4]. The human genome includes approximately 28,526 annotated genes that express approximately 120,145 transcripts, of which 80,932 are protein coding and 39,213 are non-coding transcripts [5]. The identification of "exon-level" expression profiles and characterization of AS events has become possible with the availability of exon platforms (e. g. GeneChip Exon Array). The brain exhibits particularly high rates of AS [6] and the highest number of AEU events [7]. Regulation of gene expression due to splicing has been associated with cancer. Many AEU events have been associated with disordered cell differentiation and signaling that contribute to stem cell like proliferation of cancer cells [8].

Glioblastoma multiforme (GBM) is an aggressive type of brain cancer and the role of genes and AEU on GBM survival is still not completely understood [9-11]. Most work on AS and GBM studied individual genes or compared AS between GBM and control (e.g. blood) samples. The relationship between AS and the survival of individuals diagnosed with GBM has not been studied. Understanding of the factors influencing survival is particularly important in GBM cases because the median survival after diagnosis is approximately one year $[12,13]$. Furthermore, several epidemiological factors influence GBM survival including gender, race and treatment [14]. Thus, a more accurate understanding of the relationship between AS and GBM survival must consider epidemiological factors and inter-individual variability.

Several approaches to identify AS events have been proposed. However, most approaches have limitations that can bias the identification and characterization of AEU. For example, Su et al. developed an individual exon approach that does not model the covariation between exons within a gene [15]. Purdom et al. used the residuals from probe level analysis to identify AEU on a per-sample level [16]. The sample-level analysis challenges the detection of AEU events or the identification of common patterns across patients receiving the same treatment or from the same epidemiological strata.
Laderas et al. and Zheng et al. proposed group comparison using linear models to overcome the limitations of the previous approach $[2,17]$. However, group comparison is not suited to identify AEU associated with other conditions such as survival or time-to-event. In addition, the previous implementation does not account for correlations between exons measured on the same sample. Cline et al. formulated an ANalysis Of Splice VAriation approach that cannot be used in genes that produced more than one splice form [18].

The main goal of this study is to demonstrate an exon-based, gene-centric model to detect AEU events associated with GBM survival. We developed an analytical method that addresses the limitations of previous approaches by modeling the exon-level expression profiles within genes from all samples across all treatments or conditions studied. Our approach accommodates the dependencies between exons within a gene and patient and allows testing the hypothesis of differential exon expression or usage between treatment groups. A unique advantage of our flexible approach is that one model encompasses all scenarios: i) multi-exon genes that have AEU, ii) multi-exon genes that do not have AEU, and iii) single-exon genes. A supporting goal is the three-fold assessment of the approach that encompassed; 1 ) the use separate training and validation data sets, 2) gene set enrichment and gene functional analyses of the results, and 3) comparison of predicted and reported AS events.

\section{Methods}

\section{Training data set}

Survival, clinical and exon expression information from 250 patients diagnosed with GBM was obtained from The Cancer Genome Atlas repository, May 2011 data freeze (https://tcga-data.nci.nih.gov/tcga/). Surgical samples had a minimum of $80 \%$ tumor nuclei and maximum of $50 \%$ necrosis. The clinical or epidemiological variables considered in the analysis of exon expression included treatment (levels: chemo-radiation-targeted [CRT], chemo-radiation-non targeted [CRnT], radiation $[R]$, other therapies [OTHER], and no therapy [NONE]); racial ethnicity (white Caucasian and others); and gender (male and female). These clinical factors were previously found to be associated with survival [9]. The survival indicator was the time from diagnosis to death, expressed in months.

Exon expression measurements from a frozen sample from each patient were obtained using the AffymetrixGeneChip $^{\circledR}$ Human Exon 1.0 ST Array (Affymetrix, Santa Clara, CA). This platform includes information from 1,432,143 probe sets representing known and predicted exons on both strands of the genome that have been mapped to more than 25,000 genes. Intensity data was $\log -2$ transformed and normalized using quantile 
and RMA normalization at the probe level following the procedures described in Beehive (http://stagbeetle. animal.uiuc.edu/Beehive). Probes sets within exons were collapsed using a Tukey biweight function that provides an iterative reweighed measure of central tendency. This robust statistic provides a single exon expression that is not heavily influenced by extreme probe expression levels [19].

\section{Model}

Three specifications of this model accommodated three groups of genes: 1) multi-exon genes exhibiting AEU, 2) multi-exon genes with no evidence of AEU, and 3) single-exon genes. The first, second and third model specifications correspond to equations [[1]], [[2]] and [[3]], respectively. Within gene, a general exon expression mixed model was developed to describe the association between and exon expression and GBM survival adjusted for other clinical factors:

$$
\begin{aligned}
& \mathrm{y}_{\mathrm{ijklmn}}=\mu+\mathrm{G}_{\mathrm{i}}+\mathrm{R}_{\mathrm{j}}+\mathrm{T}_{\mathrm{k}}+\mathrm{b}_{2} \mathrm{~S}_{\mathrm{l}}+\mathrm{X}_{\mathrm{m}} \\
& +\mathrm{b}_{3 \mathrm{~m}}(\mathrm{SX})_{\mathrm{lm}}+\mathrm{P}_{\mathrm{n}}+\mathrm{e}_{\mathrm{ij} \mathrm{jlm} n} \\
& \mathrm{y}_{\mathrm{ijklmn}}=\mu+\mathrm{G}_{\mathrm{i}}+\mathrm{R}_{\mathrm{j}}+\mathrm{T}_{\mathrm{k}}+\mathrm{b}_{4} \mathrm{~S}_{\mathrm{l}}+\mathrm{X}_{\mathrm{m}}+\mathrm{P}_{\mathrm{n}} \\
& +\mathrm{e}_{\mathrm{ijk} k \mathrm{mn}} \\
& \mathrm{y}_{\mathrm{ijk} k \mathrm{mn}}=\mu+\mathrm{G}_{\mathrm{i}}+\mathrm{R}_{\mathrm{j}}+\mathrm{T}_{\mathrm{k}}+\mathrm{b}_{5} \mathrm{~S}_{\mathrm{l}}+\mathrm{P}_{\mathrm{n}}+\mathrm{e}_{\mathrm{ijk} k \mathrm{lmn}}
\end{aligned}
$$

where $y_{\mathrm{ijklmn}}$ denotes the expression of the $\mathrm{m}^{\text {th }}$ exon $\left(X_{m}\right)$, recorded on the $n^{\text {th }}$ patient $\left(P_{n}\right)$ that has the $i^{\text {th }}$ gender $\left(G_{i}\right)$, $j^{\text {th }}$ race/ethnicity $\left(R_{j}\right)$, and received the $k^{\text {th }}$ therapy $\left(\mathrm{T}_{\mathrm{k}}\right)$. Survival after diagnosis $\left(\mathrm{S}_{\mathrm{l}}\right)$, expressed in months, was fitted as a covariate. The parameters $b_{2}, b_{4}$, and $b_{5}$ describe the overall change in expression per additional survival month across all exons, and $b_{3 m}$ descrbe the deviation in change in expression per additional survival month for the $\mathrm{m}^{\text {th }}$ exon in multi-exon genes that have AEU. In addition, $\mathrm{e}_{\mathrm{ijk} k \mathrm{mn}}$ is the residual associated with the $\mathrm{y}_{\mathrm{ijklmn}}$ observation, and SX denotes the interaction between survival and exon. In this model the fixed effects were; gender, race/ethnicity, therapy, and survival after diagnosis. The random effects exon, interaction between survival and exon, and patient were assumed to be independent and follow a Gaussian distribution with mean zero and its own variance.

A significant interaction between survival and exon effect constitutes evidence of an AEU scenario and, thus, differential survival across exons (group 1 genes). This model can be used to identify AS biomarkers of GBM survival that exhibit AEU. A significant survival after diagnosis effect together with a non-significant interaction between survival and exon effect constitutes evidence of a general association between gene expression and survival, regardless of exon (group 2 genes). This result can be used to identify multi-exon biomarkers of GBM survival that do not exhibit AEU.

The specification for the single-exon genes (group 3 genes) is a reduced version of the full multi-exon model that excludes exon and interaction between survival and exon. A significant survival effect is evidence of association between the single-exon gene expression and survival and can be used to identify single-exon biomarkers of GBM survival.

The hierarchical structure of the model used to identify AEU and gene expression associations with survival stems from the presence of two type of descriptive parameters: general or population-level and group-level parameters. There is a general or population-level association between exon expression and survival across all the exons of the gene, and group-level exon-specific deviations from the overall association that reveal alternative exon usage. A second hierarchical structure stems from a population-level exon expression, and patientspecific deviations from the overall expression level. The within-gene analysis supported a gene-centric strategy to uncover expression profiles associated with survival. The analysis of all exon information within a gene-allowed accounting for the covariance between exon expression within a gene and the hierarchical nature of the model allows the inclusion of the covariance between exonexpression within a patient. The analysis of expression data at the exon level permitted the identification of AEU by testing the null hypothesis of no differential association between expression and survival across exons within a gene.

False Discovery Rate adjustment (FDR) of the P-values allowed controlling for multiple testing [20]. In addition, a more stringent $\mathrm{P}$-value threshold was considered for the detection of AEU associations with a significant interaction between survival and exon) than the main survival effect in the multi-exon scenarios. The more stringent P-values required for detection of AEU accounted for the multiple comparisons of the survivalexpression associations among potentially numerous exons. A separate FDR adjustment of the P-values from the single-exon analysis was implemented because of the different number of parameters between the multi- and single-exon models. In this study, the significance threshold P-value $<5.0 \mathrm{E}-4$ corresponds to a FDRadjusted P-value $<0.05$ or multi exon genes and to a FDR adjusted P-value $<0.1$ for genes with single exon. The mixed effects model was evaluated in a restricted maximum-likelihood framework using the SAS 9.2 MIXED procedure (http://www.sas.com/).

Thus, three types of evidence were used to identify AEU: a) significant variations in the associations between exon expression and survival across a gene, b) consistent (over or under-expressed) differential expression in more 
than two consecutive exons, and c) a minimum exon differential expression $(<0.995$ or $>1.005$ fold change / additional survival month). Consistent patterns of expression across consecutive exons were identified using a moving average analysis [21]. A moving average analysis that computes the average expression across multiple exons at a time was used to predict a continuous trajectory of exon expression across the gene. This moving average trend of exon expression across the gene facilitated the identification of consistent changes in the pattern of over or under-expression across the exons within a gene.

Functional and pathway analyses of the genes exhibiting significant evidence (P-value $<5.0 \mathrm{E}-4)$ of AEU associated with GBM survival used hypergeometric tests and was implemented in DAVID [22,23]. Gene set enrichment analysis (GSEA) of the association between expression and GBM survival among all the genes studied in the platform followed the approach described by Subramanian et al. [24] implemented in BABELOMICS 4.3 [25]. For this analysis, the association between each gene and survival was characterized by the estimate of change in expression per additional survival month standardized by the standard error of the estimate. The enrichment of Gene Ontology (GO; http://www.geneontology.org/) biological processes, molecular functions, and KEGG (http://www.genome.jp/kegg/pathway.html) pathways was investigated. Finally, P-values of the enriched categories were adjusted for multiple testing using the FDR correction.

The exon expression estimates and the moving average trajectory of the estimates across individual genes were aligned to known or predicted alternative transcript variants reported in the AceView database (http://www. ncbi.nlm.nih.gov/IEB/Research/Acembly/) that are available through the UCSC Genome Browser (http:// genome.ucsc.edu). This visualization strategy facilitated the interpretation of results and the AS models offered an independent in silico confirmation of the AEU events identified.

\section{Validation dataset}

Genes exhibiting AEU in the training data set were confirmed in an independent set of 78 patients obtained from TCGA (May 2011 data freeze). The reliability of the exon expression profiles associated with survival identified in the training data set was assessed using a two-stage approach. First, the parameter estimates (i.e. changes in exon expression per one additional month of survival) that were obtained from the analysis of the training data set were applied to the covariate information from the patients in the validation data set, and predictions of exon expression were obtained. Second, the predicted exon expression values were compared to the corresponding observed expression values. The performance of the training estimates was evaluated using the coefficient of determination $\left(\mathrm{R}^{2}\right)$ that represents the fraction of the total variation of the expression associated with survival, exon and the rest of the model terms [26]. High $R^{2}$ on the validation data set based on the training data set estimates indicate the reliability of the exon expression patterns identified.

\section{Results and discussion}

Expression measurements of 269,951 exons from 25,403 genes were analyzed. Of these, 2,857, 20,288, 1,965 and 293 genes had 1,2 to 24,25 to 49 , and 50 or more exons, respectively. The number of exons per gene ranged from 1 to 191 and averaged 10.75 exons per gene. Table 1 summarizes the distribution of the 250 and 78 individuals diagnosed with GBM analyzed in the training and validation data sets respectively, across clinical factors, and survival descriptive statistics. The distribution of observations across clinical factors was consistent across data sets.

\section{Multi-exon genes exhibiting exon-dependent association with glioblastoma multiforme survival}

At a FDR-adjusted P-value $<0.05$ (approximately equivalent to an unadjusted P-value $<5.0 \mathrm{E}-4$ ) threshold, 2477 multi-exon genes exhibited AEU associated with survival (group 1 genes), 24 multi-exon genes exhibited expression associated with survival albeit no evidence of AEU (group 2 genes), and 8 single-exon genes exhibited expression associated with survival (group 3 genes). A similar number $(1,478)$ of differentially expressed genes was associated short- versus long-term glioblastoma survival [27]. The higher number of associations detected in the present study could be attributed to the analysis of exon-level profiles instead of gene-level profiles. At unadjusted P-value $<1.0 \mathrm{E}-5$, P-value $<1.0 \mathrm{E}-6$ (approximately equivalent to a FDR-adjusted P-value $<1.0 \mathrm{E}-2$ ), $\mathrm{P}$-value $<1.0 \mathrm{E}-7, \mathrm{P}$-value $<1.0 \mathrm{E}-8$ (approximately equivalent to a FDR-adjusted P-value $<5.0 \mathrm{E}-4$ ), the number of genes exhibiting AEU (group 1 genes) were $592,313,201$, and 129 respectively.

Table 2 summarizes the 36 multi-exon genes that have the most significant (P-value < 0.11) AEU or exondependent association with GBM survival (group 1 genes). Additional file 1: Table S1 lists the results for the 129 multi-exon genes that exhibit evidence of AEU at $\mathrm{P}$-value $<1.0 \mathrm{E}-8$.

The nature of the association between expression and GBM was characterized by the sign and value of the expression change per additional month in survival. Tables 2, 3 and 4 include a general, exon-independent, gene-wise estimate of expression fold change per additional survival month for completeness. The meaning of 
Table 1 Distribution of patients across clinical factors by data set

\begin{tabular}{|c|c|c|c|c|c|}
\hline & & \multicolumn{2}{|c|}{ Training data set } & \multicolumn{2}{|c|}{ Validation data set } \\
\hline & & Number & Percentage & Number & Percentage \\
\hline Patients & & 250 & 76.22 & 78 & 23.78 \\
\hline \multirow[t]{2}{*}{ Race $^{1}$} & Caucasian & 222 & 88.80 & 71 & 91.03 \\
\hline & Other & 28 & 11.20 & 07 & 8.97 \\
\hline \multirow[t]{2}{*}{ Gender } & Females & 94 & 37.60 & 29 & 37.18 \\
\hline & Males & 156 & 62.40 & 49 & 62.82 \\
\hline \multirow[t]{5}{*}{ Therapy $^{2}$} & $\mathrm{R}$ & 63 & 25.20 & 21 & 26.92 \\
\hline & CRT & 27 & 10.80 & 07 & 8.97 \\
\hline & CRnT & 99 & 39.60 & 31 & 39.74 \\
\hline & OTHER & 35 & 14.00 & 10 & 12.82 \\
\hline & NONE & 26 & 10.40 & 09 & 11.54 \\
\hline Survival (months) & & 17.46 & $0.16-128$ & 15.02 & $0.10-77.57$ \\
\hline
\end{tabular}

this fold change estimate is straightforward for genes in groups 2 and 3 because these genes exhibit a single, general, and exon-independent association with GBM survival. The general fold change estimate for group 1 genes must be considered in the context that these genes have an exon-dependent association with GBM.

The top 36 genes exhibiting significant evidence of AEU had a minimum of 90 exons (Table 2). This result suggests that genes with high number of exons are more likely to experience AEU events that influence GBM survival than genes with few exons. It is unlikely that high number of exons biased the identification of AEU due to the stringent P-value threshold used.

Most of the 36 genes that had significant AEU association with GBM survival have been associated with cancer. Relevant literature references are summarized in Table 2 . There were 10 genes including titin (Ttn), polycystic kidney disease $1(P k d 1)$, spectrin repeat containing, nuclear envelope 1 (Syne1), small nuclear ribinucleoprotein (Snrpn), phosphodiesterase 4D interacting protein (Pde4dip), obscurin (Obscn), dystonin (Dst), microtubule-actin cross-linking factor 1 (Macf1), ryanodine receptor 1 (Ryr1), and ryanodine receptor 2 (Ryr2), that had been previously associated with GBM. Additionally, 13 genes have been previously associated to cancers other than GBM including; Smg-1 homolog (Smg1), Nebulin $(\mathrm{Neb})$, TBC1 domain family, member 3 (Tbc1d3), Anaphase promoting complex subunit 1 (Anapc1), Spectrin repeat containing, nuclear envelope 1 (Syne2), Neuroblastoma breakpoint family, member 10 (Nbpf10), Mucin 19 (Muc19), Collagen, type VII, alpha 1 (Col7a1), Ubiquitin protein ligase E3 component nrecognin 4 (Ubr4), Hemicentin 1 (Hmcn1), Collagen, type IV, alpha 5 (Col4a5), Ryanodine receptor 3 (Ryr3), and G protein-coupled receptor 98 (Gpr98).
Previous reports confirmed the overall relationship between the top genes exhibiting AEU and GBM identified in this study. Reports on the overall relationship between genes and GBM are hereby reviewed since the AEU pattern for these genes has not been previously described. The TTN protein is encoded by Ttn, and is responsible for the passive elasticity of cells. A mutation resulting in an altered TTN was associated with GBM [28]. Pkd1 was over-expressed during the progression of low-grade to high-grade gliomas [32]. Syne1 has been associated with increased GBM survival [9]. Under-expression of Snrnp was observed in older GBM patients compared to younger patients [33]. Pde4dip is down-regulated in glioma cell lines treated with $\mathrm{dB}$-cAMP that reduces the invasiveness, proliferation and migratory properties of glioma cells and increases the survival of glioma cells lines compared to untreated cell lines [35]. The mutation $\mathrm{R} 4558 \mathrm{H}$ in $\mathrm{Obscn}$ has been associated with GBM [28]. Likewise, a mutation in Dst that indirectly regulates the expression of Otub1 (through regulation of mir-15b has been associated with GBM [44]. Reduced expression of Macf1 has been observed in glioma cells treated with IL-13 cytotoxin that causes the cells to undergo necrosis. Thus, down-regulation of the expression of Macf1 was associated with increased GBM survival [53]. Ryr1 was under-expressed in high-grade gliomas relative to primary (low-grade) gliomas [57]. On the other hand, Ryr2 was over-expressed in invasive GBM cells compared to normal control cells [51].

Functional and pathway analyses of the multi-exon genes exhibiting exon-independent association with glioblastoma multiforme survival

The 2,477 genes exhibiting significant evidence of AEU associated with GBM survival were further investigated 
Table 2 Top 36 multi-exon genes that have significant alternative exon usage associated with glioblastoma multiforme survival

\begin{tabular}{|c|c|c|c|c|c|c|}
\hline Gene Symbol & Estimate $^{1}$ & $\mathrm{SE}^{2}$ & $\mathrm{P}$-value $\mathrm{AEU}^{3}$ & Fold change $^{4}$ & Exon Count $^{5}$ & Literature $^{6}$ \\
\hline$\overline{T t n}$ & 0.0007 & 0.0001 & $4.2 E-38$ & 0.9993 & 340 & {$[28]^{G}$} \\
\hline Smgl & 0.0017 & 0.0002 & $2.0 \mathrm{E}-24$ & 1.0001 & 209 & {$[29]^{\mathrm{AS}}$} \\
\hline$\overline{\mathrm{Neb}}$ & 0.0007 & 0.0001 & $3.2 \mathrm{E}-21$ & 0.9973 & 180 & {$[30,31]^{C, A S}$} \\
\hline$\overline{P k d 1}$ & 0.0010 & 0.0001 & $2.0 \mathrm{E}-19$ & 1.0018 & 163 & {$[32]^{\mathrm{G}, \mathrm{AS}}$} \\
\hline Herc2p2 & 0.0008 & 0.0001 & $2.3 \mathrm{E}-19$ & 1.0012 & 163 & NA \\
\hline Syne1 & 0.0018 & 0.0002 & $3.0 \mathrm{E}-18$ & 0.9984 & 152 & {$[9]^{G}$} \\
\hline Snrpn & 0.0018 & 0.0002 & $3.8 \mathrm{E}-18$ & 1.0020 & 151 & {$[33,34]^{G, A S}$} \\
\hline Pde4dip & 0.0016 & 0.0002 & $1.3 \mathrm{E}-17$ & 0.9993 & 146 & {$[35,36]^{G, A S}$} \\
\hline Golga8c & 0.0031 & 0.0004 & $4.2 \mathrm{E}-17$ & 1.0005 & 141 & NA \\
\hline Sspo & 0.0009 & 0.0001 & $1.2 \mathrm{E}-16$ & 1.0003 & 137 & NA \\
\hline Ankrd36 & 0.0026 & 0.0003 & $1.3 \mathrm{E}-16$ & 1.0018 & 137 & NA \\
\hline$T b c 1 d 3$ & 0.0008 & 0.0001 & $2.4 \mathrm{E}-16$ & 1.0026 & 135 & {$[37]^{C}$} \\
\hline Flj45340 & 0.0018 & 0.0002 & $5.5 \mathrm{E}-16$ & 1.0007 & 131 & NA \\
\hline Anapc1 & 0.0009 & 0.0001 & $5.8 \mathrm{E}-15$ & 0.9990 & 122 & {$[38,39]^{C,}$ AS } \\
\hline Syne2 & 0.0012 & 0.0002 & $6.2 \mathrm{E}-15$ & 1.0017 & 115 & {$[40]^{C,}$ AS } \\
\hline Nbpf10 & 0.0035 & 0.0005 & $1.3 \mathrm{E}-14$ & 0.9992 & 118 & {$[41]^{C, A S}$} \\
\hline Muc19 & 0.0015 & 0.0002 & $1.4 \mathrm{E}-14$ & 1.0001 & 118 & {$[42]^{C, A S}$} \\
\hline Obscn & 0.0006 & 0.0001 & $1.5 \mathrm{E}-14$ & 0.9999 & 118 & {$[28,43]^{\mathrm{G}, \mathrm{AS}}$} \\
\hline Npip/3 & 0.0019 & 0.0003 & $4.1 \mathrm{E}-14$ & 1.0014 & 114 & NA \\
\hline$\overline{D s t}$ & 0.0013 & 0.0002 & $9.4 \mathrm{E}-14$ & 0.9997 & 111 & {$[44,45]^{G, A S}$} \\
\hline Col7a1 & 0.0011 & 0.0001 & $1.4 \mathrm{E}-13$ & 1.0001 & 109 & {$[46,47]^{C, A S}$} \\
\hline Ubr4 & 0.0011 & 0.0001 & $1.4 \mathrm{E}-13$ & 0.9994 & 109 & {$[48,49]^{C,}$ AS } \\
\hline$\overline{H m c n 1}$ & 0.0006 & 0.0001 & $2.0 \mathrm{E}-13$ & 0.9975 & 109 & {$[50]^{C, A S}$} \\
\hline Ryr2 & 0.0011 & 0.0001 & $2.7 \mathrm{E}-13$ & 0.9974 & 107 & {$[51,52]^{\mathrm{G}, \mathrm{AS}}$} \\
\hline$\overline{\text { Macfl }}$ & 0.0011 & 0.0002 & $3.1 \mathrm{E}-13$ & 0.9975 & 106 & {$[53,54]^{G,}$ AS } \\
\hline$\overline{M d n 1}$ & 0.0006 & 0.0001 & $3.5 \mathrm{E}-13$ & 0.9993 & 106 & NA \\
\hline Col4a5 & 0.0008 & 0.0001 & $3.5 \mathrm{E}-13$ & 0.9992 & 106 & {$[55,56]^{C, A S}$} \\
\hline Ryr1 & 0.0007 & 0.0001 & $4.2 \mathrm{E}-13$ & 0.9998 & 105 & {$[31,57,58]^{\mathrm{G}, \mathrm{AS}}$} \\
\hline Golga615 & 0.0013 & 0.0002 & $5.2 \mathrm{E}-13$ & 1.0021 & 104 & NA \\
\hline Ryr3 & 0.0009 & 0.0001 & 1.3E-12 & 0.9962 & 102 & {$[59]^{C, A S}$} \\
\hline Dnah14 & 0.0007 & 0.0001 & $2.0 \mathrm{E}-12$ & 0.9990 & 99 & NA \\
\hline Herc2 & 0.0006 & 0.0001 & $3.1 \mathrm{E}-12$ & 1.0003 & 97 & {$[60]^{\mathrm{AS}}$} \\
\hline Dnah8 & 0.0005 & 0.0001 & 4.7E-12 & 0.9997 & 96 & NA \\
\hline Nomo 1 & 0.0007 & 0.0001 & $4.9 \mathrm{E}-12$ & 0.9996 & 95 & NA \\
\hline Gpr98 & 0.0016 & 0.0002 & $5.9 \mathrm{E}-12$ & 0.9948 & 95 & {$[61]^{C, A S}$} \\
\hline Golga6a & 0.0017 & 0.0002 & $7.8 \mathrm{E}-12$ & 1.0009 & 93 & NA \\
\hline
\end{tabular}

${ }^{1}$ Estimate: exon-survival interaction variance indicator of alternative exon usage.

${ }^{2} \mathrm{SE}$ : standard error of the estimate.

${ }^{3} \mathrm{P}$-value AEU: unadjusted P-value of alternative exon usage or exon-dependent association between expression and glioblastoma multiforme survival.

${ }^{4}$ Fold change: fold change in average exon expression per additional survival month.

${ }^{5}$ Exon Count: number of exons in the gene.

${ }^{6}$ Literature: review of studies that reported associations of the gene with cancers:

$G$ : reported association of gene with glioblastoma multiforme,

$c$ : reported association of gene with cancer other than glioblastoma multiforme,

As: identification of different variants due to alternative splicing (AS) event,

NA: not available. 
Table 3 Ten most significant KEGG and GO categories enriched among the genes displaying alternative exon usage

\begin{tabular}{|c|c|c|c|}
\hline Source & Category & Gene Count ${ }^{1}$ & FDR P-value ${ }^{2}$ \\
\hline \multirow[t]{10}{*}{ KEGG Pathway } & (hsa04510) focal adhesion & 86 & $3.2 \mathrm{E}-21$ \\
\hline & (hsa04512) ecm-receptor interaction & 51 & $8.5 \mathrm{E}-20$ \\
\hline & (hsa02010) abc transporters & 30 & $2.5 \mathrm{E}-12$ \\
\hline & (hsa04810) regulation of actin cytoskeleton & 66 & 1.7E-07 \\
\hline & (hsa05412) arrhythmogenic right ventricular cardiomyopathy & 32 & $5.9 \mathrm{E}-06$ \\
\hline & (hsa05414) dilated cardiomyopathy & 37 & $1.3 \mathrm{E}-06$ \\
\hline & (hsa04070) phosphatidylinositol signaling system & 31 & $1.2 \mathrm{E}-05$ \\
\hline & (hsa05222) small cell lung cancer & 31 & 3.6E-04 \\
\hline & (hsa05410) hypertrophic cardiomyopathy & 32 & 1.3E-04 \\
\hline & (hsa05200) pathways in cancer & 73 & $3.0 \mathrm{E}-02$ \\
\hline \multirow[t]{10}{*}{ GO Biological Process } & (GO:0051056) regulation of small GTPase mediated signal transduction & 105 & 0.055 \\
\hline & (GO:0022610) biological adhesion & 197 & 2.7E-22 \\
\hline & (GO:0007155) cell adhesion & 197 & $2.3 \mathrm{E}-22$ \\
\hline & (GO:0046578) regulation of Ras protein signal transduction & 79 & $5.0 \mathrm{E}-15$ \\
\hline & (GO:0035023) regulation of Rho protein signal transduction & 51 & 1.7E-15 \\
\hline & (GO:0007010) cytoskeleton organization & 129 & $1.3 \mathrm{E}-15$ \\
\hline & (GO:0030029) actin filament-based process & 85 & $2.3 \mathrm{E}-14$ \\
\hline & (GO:0007018) microtubule-based movement & 51 & $2.1 \mathrm{E}-12$ \\
\hline & (GO:0016568) chromatin modification & 89 & $1.9 \mathrm{E}-12$ \\
\hline & (GO:0051276) chromosome organization & 132 & 1.4E-12 \\
\hline \multirow[t]{10}{*}{ GO Molecular Function } & (GO:0030554) adenyl nucleotide binding & 451 & $9.9 \mathrm{E}-59$ \\
\hline & (GO:0005524) ATP binding & 433 & $2.2 \mathrm{E}-59$ \\
\hline & (GO:0032559) adenyl ribonucleotide binding & 437 & $2.0 \mathrm{E}-59$ \\
\hline & (GO:0001882) nucleoside binding & 456 & $6.3 \mathrm{E}-58$ \\
\hline & (GO:0001883) purine nucleoside binding & 451 & $1.5 \mathrm{E}-56$ \\
\hline & (GO:0017076) purine nucleotide binding & 480 & $5.2 \mathrm{E}-44$ \\
\hline & (GO:0032555) purine ribonucleotide binding & 466 & $2.9 \mathrm{E}-44$ \\
\hline & (GO:0032553) ribonucleotide binding & 466 & $2.9 \mathrm{E}-44$ \\
\hline & (GO:0000166) nucleotide binding & 523 & 7.4E-39 \\
\hline & (GO:0003774) motor activity & 86 & $1.3 \mathrm{E}-34$ \\
\hline
\end{tabular}

${ }^{1}$ Gene Count: number of genes that have significant alternative exon usage within category.

${ }^{2}$ FDR-adjusted P-value: False discovery rate adjusted P-value of the hypergeometric test of category enrichment.

using functional and pathway analyses. At FDRadjusted P-value $<0.05,15$ KEGG pathways, $87 \mathrm{GO}$ biological processes, and $70 \mathrm{GO}$ molecular functions were enriched. The top 10 pathways, biological processes and molecular functions are summarized in Table 3. Additional file 1: Table S2 lists all KEGG pathways and GO categories with FDR-adjusted Pvalue $<0.05$. Among the 15 pathways significantly enriched, focal adhesion was the most significant pathway encompassing 86 genes. This result was consistent with many reports of the critical role of focal adhesion and gliomas [66-68]. The enrichment of the extracellular matrix- (ECM-) receptor interaction pathway detected in this study has been reported in other cancers $[69,70]$. The ATP-binding cassette (ABC) transporter pathway has been associated with gliomas [71]. Our finding of small cell lung carcinoma pathways enrichment associated with GBM was consistent with the multiple studies that have identified commonalities among these cancers [72]. The most enriched biological process among the AEU genes associated with GBM survival included regulation of small GTPase mediated signal transduction (RSGST), and neuron development that has been associated with neuroblastoma [73]. The enrichment of biological adhesion confirms our focal adhesion results. Among the top $70 \mathrm{GO}$ molecular functions significantly enriched were adenyl ribonucleotide binding, ATP binding, 
Table 4 Top 5 multi-exon genes that have significant exon-independent association with glioblastoma multiforme survival

\begin{tabular}{|c|c|c|c|c|c|c|c|}
\hline Gene Symbol & Estimate $^{1}$ & $\mathrm{SE}^{2}$ & Fold Change $^{3}$ & P-value $^{4}$ & P-value $\mathrm{AEU}^{5}$ & Exon Count ${ }^{6}$ & Literature $^{7}$ \\
\hline Sirt2 & 0.0337 & 0.0092 & 1.0236 & $3.2 \mathrm{E}-04$ & $2.5 \mathrm{E}-03$ & 17 & {$[62]^{G}$} \\
\hline Six 1 & 0.0056 & 0.0015 & 1.0039 & $3.3 \mathrm{E}-04$ & 2.7E-01 & 5 & {$[63]^{c}$} \\
\hline Loc100289627 & 0.0079 & 0.0022 & 1.0055 & $3.8 \mathrm{E}-04$ & 4.3E-01 & 2 & NA \\
\hline semaze & -0.0256 & 0.0066 & 0.9824 & $1.3 \mathrm{E}-04$ & $2.4 \mathrm{E}-03$ & 18 & {$[64]^{C}$} \\
\hline Golga8j & -0.0536 & 0.0141 & 0.9635 & 1.7E-04 & $1.1 \mathrm{E}-03$ & 20 & {$[65]^{C}$} \\
\hline
\end{tabular}

${ }^{1}$ Estimate: change in average exon expression per additional survival month (in log2 units).

${ }^{2} \mathrm{SE}$ : standard error of the estimate.

${ }^{3}$ Fold change: fold change in average exon expression per additional survival month.

${ }^{4} \mathrm{P}$-value: unadjusted $\mathrm{P}$-value of the change in average exon expression per additional survival month.

${ }^{5} \mathrm{P}$-value AEU: non-significant ( $\mathrm{P}$-value $>1.0 \mathrm{E}-03$ ) evidence of alternative exon usage.

${ }^{6}$ Exon Count: number of exons in the gene.

${ }^{7}$ Literature: review of studies that reported associations of the gene with cancers:

$\mathrm{G}$ : reported association of gene with glioblastoma multiforme,

$C_{\text {: }}$ reported association of gene with cancer other than glioblastoma multiforme,

NA: not available.

nucleotide binding and helicase activity. These related nucleotide binding functions have been associated with GBM [74].

\section{Multi-exon genes exhibiting exon-independent association with glioblastoma multiforme survival}

At unadjusted P-value < 5.0E-4, 24 multi-exon genes exhibited exon-independent association with GBM survival (group 2 genes). In other words, there was no evidence of AEU in these genes because the expressions of all the exons were consistently associated with GBM survival and a single general or overall association between the gene and survival can be identified. Table 4 lists the top five multi-exon genes that have the most significant exon-independent association with GBM survival. Additional file 1: Table S3 lists the results for the 24 multiexon genes exhibiting expression associated with survival albeit no evidence of AEU at P-value < 5.0E-4.

Among the 24 multi-exon genes that were associated with GBM survival on a general, exon-independent manner, the five genes that have the lower AEU evidence (AEU unadjusted P-value > 1.0E-3, approximately FDR adjusted P-value $>0.1$ ) are listed in Table 4 . The expression of three of these genes increased with increasing survival. Noteworthy was the low number of exons in these genes, relative to the higher number of exons in genes exhibiting evidence of AEU.

Four of five multi-exon genes have been associated to different cancers in studies listed in Table 4, and the remaining gene (LOC100289627) is similar to Guanine nucleotide-binding protein subunit beta-2-like 1. Sirtuin2 (Sirt2) has been associated with GBM while the other three genes golgin subfamily A member 8J (Golga8j), semaphorin 3E (Sema3e) and SIX homeobox 1 (SIX1) were associated with other cancers. Underexpression of Sirt 2 has been reported in glioma cells relative to control cells [62]. This result is also consistent with our findings that higher levels of Sirt2 were associated with higher GBM survival Golga8j has been associated with pancreatic cancer and the trend is consistent with our finding of lower GBM survival with higher expression levels of this gene [65]. Sema3e promotes invasiveness and metastatic ability of the cancerous cells [64]. Sema3e is associated with many cancers like prostate cancer colon cancer and lung adenocarcinoma [75]. This result is consistent with our findings that higher levels of Sema3e were associated with lower GBM survival. The gene Six 1 is associated with lower survival in cancerous cells [63]. This result is inconsistent with our results showing an increase in Six 1 expression associated with an increase in GBM survival.

\section{Single-exon genes associated with glioblastoma multiforme survival}

Eight single-exon genes were associated with GBM survival (group 3 genes) at unadjusted P-value $<$ 5.0E-4 (Table 5). Among these, three genes had a negative relationship such that lower expression levels were associated with higher survival. Four members of the family of small nucleolar RNA CD box (Snord) genes were associated with GBM survival, and three had a positive association such that higher expression levels were associated with higher survival. Snord are a type of small nucleolar RNA (SnoRNA) that guides the methylation of rRNAs and snRNAs. These snoRNAs can target other RNAs and are associated with carcinogenesis. Reduced and dysregulated expression of snoRNAs have been associated with progression of many human malignancies [78]. Along with their loss in brain tumorigenesis, snoRNAs have been also linked to other cancers such as prostate, breast and lung cancer [76,78]. In this study, a positive association between the levels of $\mathrm{H} 1$ histone family member 0 (H1fO) and GBM survival was identified. The expression of $H 1 f O$ was high in breast 
Table 5 Single-exon genes associated with glioblastoma multiforme survival

\begin{tabular}{|c|c|c|c|c|c|}
\hline Gene symbol & Estimate $^{1}$ & $\mathrm{SE}^{2}$ & Fold Change $^{3}$ & P-value $^{4}$ & Literature $^{5}$ \\
\hline Hist1h1t & 0.0118 & 0.0024 & 1.0082 & $2.5 \mathrm{E}-06$ & NA \\
\hline Snord116-11 & 0.0101 & 0.0025 & 1.0070 & 9.7E-05 & {$[76]^{C}$} \\
\hline Loc729852 & -0.0074 & 0.0018 & 0.9949 & $5.8 \mathrm{E}-05$ & NA \\
\hline Snord 123 & -0.0087 & 0.0025 & 0.9940 & $4.8 \mathrm{E}-04$ & {$[76]^{C}$} \\
\hline Snord104 & 0.0067 & 0.0019 & 1.0047 & 4.1E-04 & {$[76]^{C}$} \\
\hline Dkfzp779/1853 & -0.0083 & 0.0023 & 0.9943 & $3.9 \mathrm{E}-04$ & NA \\
\hline HifO & 0.0062 & 0.0017 & 1.0043 & $2.3 \mathrm{E}-04$ & {$[77]^{c}$} \\
\hline Snord28 & 0.0166 & 0.0044 & 1.0116 & $1.8 \mathrm{E}-04$ & {$[76]^{C}$} \\
\hline
\end{tabular}

${ }^{1}$ Estimate: change in gene expression per additional survival month (in log2 units).

${ }^{2} \mathrm{SE}$ : standard error of the estimate.

${ }^{3}$ Fold change: fold change in gene expression per additional survival month.

${ }^{4} \mathrm{P}$-value: unadjusted P-value of the change in average exon expression per additional survival month;

${ }^{5}$ Literature: review of studies that reported associations of the gene with cancers:

$c_{\text {: }}$ reported association of gene with cancers other than glioblastoma multiforme,

NA: not available.

tumor cells, and decreased when the breast tumor cell lines were reverted-back into normal ME carcinoma cells [77].

\section{Gene set enrichment analyses of all genes in consideration of their association with glioblastoma multiforme survival}

Gene set enrichment analysis considered the level and sign of association between the expression of all the genes studied and GBM survival. At FDR-adjusted P-value < 0.05, 94 KEGG pathways, 402 GO biological processes, and $203 \mathrm{GO}$ molecular functions were enriched. Results from the top 10 most significant pathways, biological processes and molecular functions are summarized in Tables 6, 7 and 8. Additional file 1: Table S4, S5 and S6 lists all biological processes, molecular functions and pathways respectively that have FDR-adjusted P-value < 0.05. Pathways and GO categories are characterized in GSEA by the number of genes that have a positive or negative association between expression and GBM survival, by the log odds ratio indicating whether the category is more enriched among the genes that have a positive or negative association and the corresponding P-value.

Noteworthy was that all top ten results had negative $\log$ odds ratio indicating that the categories were more enriched among the genes that have a negative association between expression and survival relative to the enrichment among the genes that have a positive association between expression and GBM survival. Negative $\log _{\mathrm{e}}$ odds ratio indicates that the enrichment was higher among the genes with negative association

Table 6 Ten most significant GO biological processes from the gene set enrichment analysis of the genome

\begin{tabular}{|c|c|c|c|c|c|}
\hline GO Identifier & GO Biological Process & Over-Expressed Gene $^{1}$ & Under-Expressed Genes $^{2}$ & Log Odds Ratio ${ }^{3}$ & FDR P-value $^{4}$ \\
\hline GO:0046907 & intracellular transport & 357 & 560 & -0.7338 & $3.79 \mathrm{E}-24$ \\
\hline GO:0034613 & cellular protein localization & 245 & 433 & -0.8490 & $4.78 \mathrm{E}-24$ \\
\hline GO:0043067 & regulation of programmed cell death & 351 & 490 & -0.6110 & $1.68 \mathrm{E}-15$ \\
\hline GO:0016192 & vesicle-mediated transport & 271 & 400 & -0.6639 & $1.16 \mathrm{E}-14$ \\
\hline GO:0006629 & lipid metabolic process & 424 & 538 & -0.5148 & 1.30E-12 \\
\hline GO:0044265 & cellular macromolecule catabolic process & 373 & 485 & -0.5379 & $2.10 \mathrm{E}-12$ \\
\hline GO:0044255 & cellular lipid metabolic process & 346 & 457 & -0.5528 & $2.41 \mathrm{E}-12$ \\
\hline GO:0050793 & regulation of developmental process & 442 & 549 & -0.4932 & 4.27E-12 \\
\hline GO:0007049 & cell cycle & 418 & 522 & -0.4978 & $1.11 \mathrm{E}-11$ \\
\hline GO:0009966 & regulation of signal transduction & 414 & 509 & -0.4812 & $9.93 \mathrm{E}-11$ \\
\hline
\end{tabular}

${ }^{1}$ Over-Expressed Genes: number of genes that have a positive association between expression and glioblastoma multiforme survival.

${ }^{2}$ Under-Expressed Genes: number of genes that have a negative association between expression and glioblastoma multiforme survival.

${ }^{3}$ Log Odds Ratio: indicates whether the category is more enriched among the genes that have a positive association between expression and survival relative to the enrichment among the genes that have a negative association between expression and glioblastoma survival (positive loge odds ratio) or vice versa (negative $\log _{e}$ odds ratio). Extreme values indicate higher difference in the enrichment percentages between the positive and negative association groups meanwhile values close to zero indicate similar enrichment percentages between positive and negative association groups.

${ }^{4}$ FDR-adjusted P-value: False discovery rate adjusted P-value of the log odds ratio test. 
Table 7 Ten most significant GO molecular functions from the gene set enrichment analysis

\begin{tabular}{|c|c|c|c|c|c|}
\hline $\begin{array}{c}\text { GO } \\
\text { Identifier }\end{array}$ & GO Molecular Function & $\begin{array}{l}\text { Over-Expressed } \\
\text { Gene }^{1}\end{array}$ & $\begin{array}{l}\text { Under-Expressed } \\
\text { Genes }^{2}\end{array}$ & $\begin{array}{l}\text { Log Odds } \\
\text { Ratio }^{3}\end{array}$ & $\begin{array}{l}\text { FDR P- } \\
\text { value }^{4}\end{array}$ \\
\hline GO:0000287 & magnesium ion binding & 196 & 300 & -0.6962 & $3.23 \mathrm{E}-11$ \\
\hline GO:0016818 & $\begin{array}{l}\text { hydrolase activity, acting on acid anhydrides, in phosphorus } \\
\text { containing anhydrides }\end{array}$ & 419 & 521 & -0.4933 & $5.21 \mathrm{E}-11$ \\
\hline GO:0016462 & pyrophosphatase activity & 417 & 520 & -0.4962 & $5.21 \mathrm{E}-11$ \\
\hline GO:0016817 & hydrolase activity, acting on acid anhydrides & 428 & 527 & -0.4834 & $9.62 \mathrm{E}-11$ \\
\hline GO:0016773 & phosphotransferase activity, alcohol group as acceptor & 393 & 475 & -0.4624 & $5.64 \mathrm{E}-09$ \\
\hline GO:0016301 & kinase activity & 421 & 501 & -0.4473 & 5.64E-09 \\
\hline GO:0016788 & hydrolase activity, acting on ester bonds & 349 & 429 & -0.4781 & $9.84 \mathrm{E}-09$ \\
\hline GO:0003723 & RNA binding & 357 & 437 & -0.4741 & $9.84 \mathrm{E}-09$ \\
\hline GO:0030695 & GTPase regulator activity & 193 & 260 & -0.5651 & 4.10E-07 \\
\hline GO:0016874 & ligase activity & 205 & 272 & -0.5501 & 4.10E-07 \\
\hline
\end{tabular}

${ }^{1}$ Over-Expressed Genes: number of genes that have a positive association between expression and glioblastoma multiforme survival.

${ }^{2}$ Under-Expressed Genes: number of genes that have a negative association between expression and glioblastoma multiforme survival.

${ }^{3}$ Log Odds Ratio: indicates whether the category is more enriched among the genes that have a positive association between expression and survival relative to the enrichment among the genes that have a negative association between expression and glioblastoma survival (positive log $\mathrm{e}_{\mathrm{e}}$ ods ratio) or vice versa (negative $\log _{e}$ odds ratio). Extreme values indicate higher difference in the enrichment percentages between the positive and negative association groups meanwhile values close to zero indicate similar enrichment percentages between positive and negative association groups.

${ }^{4}$ FDR-adjusted P-value: False discovery rate adjusted P-value of the log odds ratio test.

with GBM survival. Positive log odds ratios were observed for less significant (P-value $<0.05$ ) pathways and categories. The more extreme log odds ratios observed in the GSEA of KEGG pathways indicate higher difference between the enrichment percentages in the positive and negative association groups meanwhile values close to zero in the GSEA of GO categories indicate lower differences in the enrichment percentages between positive and negative association groups.
Among the most differentially enriched pathways (Table 6) were the pancreatic and non-small cell lung cancer pathways. Additional pathways identified in this study that have been associated with gliomas include glycolysis/gluconeogenesis [79] and oxidative phosphorylation [80]. Among the top enriched GO biological processes, lipid metabolism and cell cycle have been associated with glioma [81,82]. Likewise, the GO molecular functions of hydrolase and ligase activity have been linked to glioma $[83,84]$.

Table 8 Ten most significant KEGG pathways from the gene set enrichment analysis of the genome

\begin{tabular}{|c|c|c|c|c|c|}
\hline $\begin{array}{l}\text { KEGG } \\
\text { Identifier }\end{array}$ & KEGG Pathway & $\begin{array}{l}\text { Over-Expressed } \\
\text { Gene }^{1}\end{array}$ & $\begin{array}{l}\text { Under-Expressed } \\
\text { Genes }^{2}\end{array}$ & $\begin{array}{l}\text { Log Odds } \\
\text { Ratio }^{3}\end{array}$ & $\begin{array}{l}\text { FDR P- } \\
\text { value }^{4}\end{array}$ \\
\hline hsa03010 & ribosome & 119 & 16 & -2.4779 & 9.7E-10 \\
\hline hsa00010 & glycolysis / gluconeogenesis & 57 & 27 & -1.1614 & $3.6 \mathrm{E}-04$ \\
\hline hsa00190 & oxidative phosphorylation & 103 & 39 & -0.9392 & $3.6 \mathrm{E}-04$ \\
\hline hsa05212 & pancreatic cancer & 54 & 45 & -0.9460 & 4.7E-04 \\
\hline hsa05130 & pathogenic escherichia coli infection & 44 & 41 & -1.0575 & 4.7E-04 \\
\hline hsa00240 & pyrimidine metabolism & 42 & 78 & -0.8800 & $5.0 \mathrm{E}-04$ \\
\hline hsa03050 & proteasome & 33 & 32 & -1.0965 & 7.2E-04 \\
\hline hsa00280 & $\begin{array}{l}\text { valine, leucine and isoleucine } \\
\text { degradation }\end{array}$ & 20 & 48 & -1.1353 & 8.5E-04 \\
\hline hsa04662 & b cell receptor signaling pathway & 34 & 65 & -0.9084 & $8.5 \mathrm{E}-04$ \\
\hline hsa05223 & non-small cell lung cancer & 25 & 52 & -0.9922 & $9.0 \mathrm{E}-04$ \\
\hline
\end{tabular}

${ }^{1}$ Over-Expressed Genes: number of genes that have a positive association between expression and glioblastoma multiforme survival.

${ }^{2}$ Under-Expressed Genes: number of genes that have a negative association between expression and glioblastoma multiforme survival.

${ }^{3}$ Log Odds Ratio: indicates whether the category is more enriched among the genes that have a positive association between expression and survival relative to the enrichment among the genes that have a negative association between expression and glioblastoma survival (positive log odds ratio) or vice versa (negative $\log _{e}$ odds ratio). Extreme values indicate higher difference in the enrichment percentages between the positive and negative association groups meanwhile values close to zero indicate similar enrichment percentages between positive and negative association groups.

${ }^{4}$ FDR-adjusted P-value: False discovery rate adjusted P-value of the log odds ratio test. 


\section{Demonstration of alternative exon usage}

The identification of patterns of differential exon expression across a gene and comparison against predicted AS models helped to confirm associations between AS and survival. Figures 1 and 2 depict patterns of exon expression associated with GBM survival and reported AS gene models for two genes that exhibited significant AEU associated with GBM survival. The patterns of two other genes that exhibited AEU are presented in Additional file 2: Figures $\mathrm{S} 1$ and $\mathrm{S} 2$. The two genes depicted in Figures 1 and 2 are G-protein coupled receptor 98 (Gpr 98$)$ and epidermal growth factor (Egf), respectively: The two genes depicted in the Additional file 2: Figures $\mathrm{S} 1$ and $\mathrm{S} 2$ are anaphase promoting complex subunit 1 (Anapc1) and HECT domain and RLD domain containing E3 ubiquitin protein ligase 2 (Herc2), respectively. The parallel alignment of estimated exon expression resulting from our analysis, the moving average trend, and the AS prediction from AceView offered in silico verification of the identified AEU [2]. The AS models are denoted by lines parallel to the $\mathrm{x}$-axis and identify the corresponding exons. However, no expression values should be assigned to the AS model lines and experimental confirmation of the AEU cases identified in this study is necessary.

Gpr98 is located on chromosome 5 and is highly expressed in the central nervous system (CNS) [85]. This gene has been associated with Usher syndrome characterized by hearing loss and progressive vision loss and Familial Febrile seizures [86,87]. Gpr 98 has been linked to cancer [88] and smaller variants of Gpr98, produced due to AS, have been associated with increased survival against lymphoblastic leukemia [61]. Gpr98 exhibited AEU in this study and the expression of approximately 30 exons (out of 90 exons) exhibited significant association with GBM survival (Figure 1). Several over-expressed exons detected by our model are consistent with AS gene models including Mass1b, Mass1f, Mass1e, and Mass1c. Conversely, some under-expressed exons identified in our study are supported by gene models including Mass1d and Mass1g. These results are consistent with previous studies that indicated association of smaller transcripts of Gpr 98 with cancer survival by inducing apoptosis in cancerous cells [61]. In agreement with our GO analyses, Gpr98 is affiliated to the enriched GO biological processes of cell adhesion, neuron development and sensory perception of mechanical stimulus. Additionally, Gpr98 has the GO molecular function of cytoskeletal protein binding and ion binding. For Gpr98, the relative difference in $\mathrm{R}^{2}$ between the training and validation data sets was $18.1 \%$. The Pearson correlation of the exon-survival associations between the training and validation data sets was $83.2 \%$.

Egf is located on HAS 4 and over-expression of Egf has been associated with tumor progression and lower GBM survival [89]. Egf exhibited AEU and of the 24

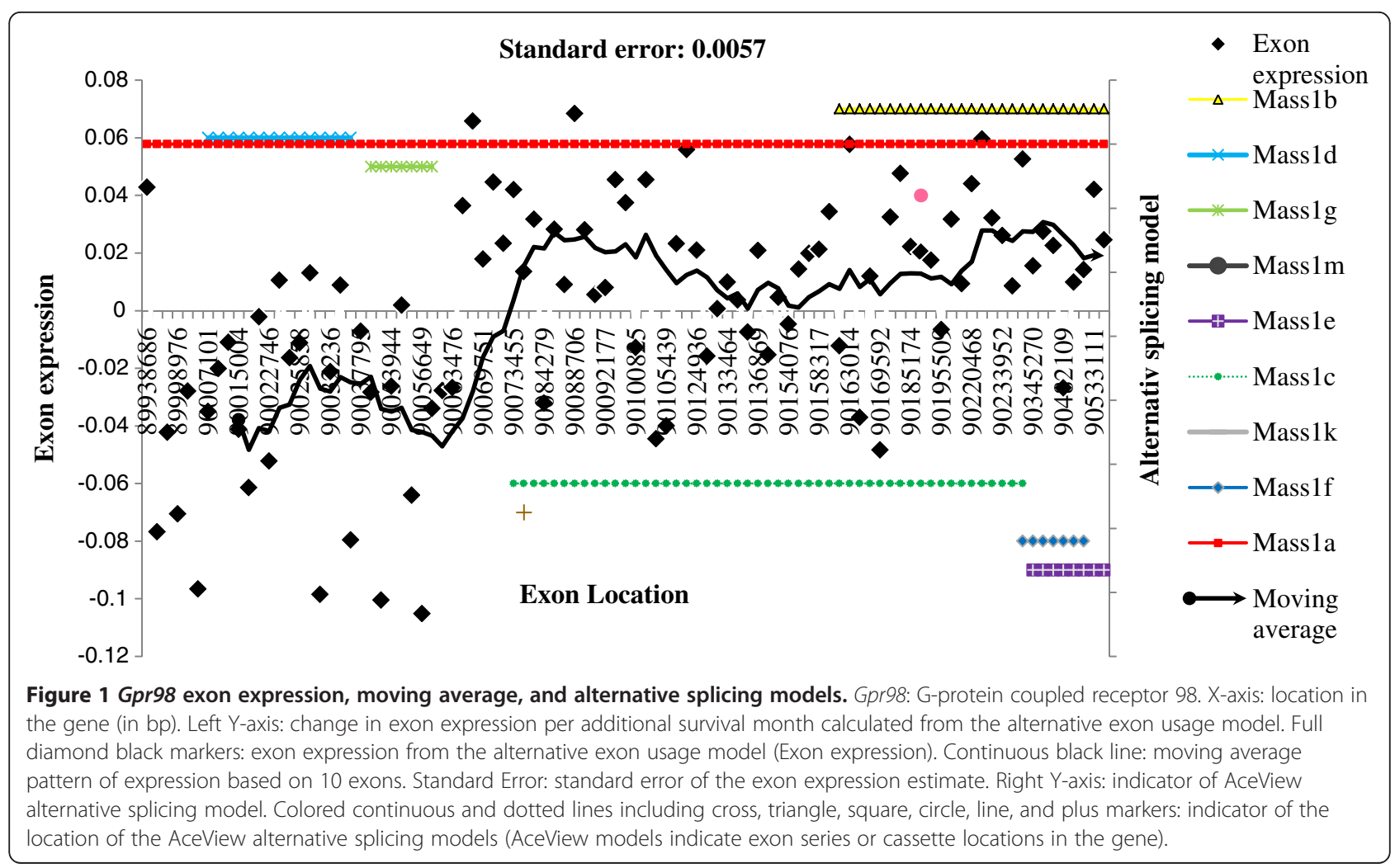




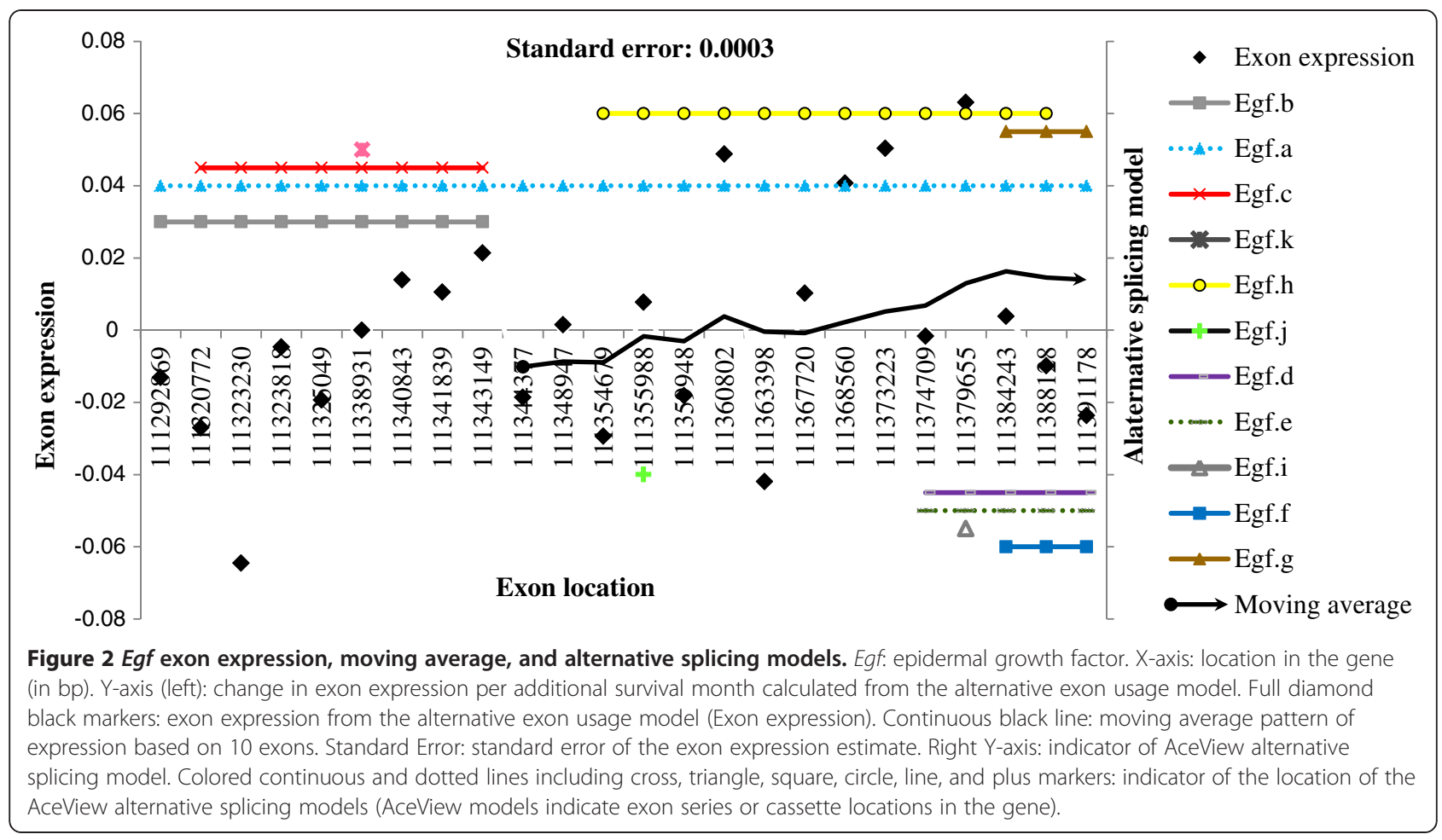

exons analyzed, nine exons had significant associations with GBM survival. Several over-expressed exons detected in our analysis correspond to AS gene models including jdec03 and hdec03 (Figure 2). In accord with the pathway and functional analyses, Egf is part of many enriched KEGG pathways including focal adhesion, regulation of actin cytoskeleton, and cancer pathways. For $E g f$, the relative difference in $\mathrm{R}^{2}$ between the training and validation data sets was $24.9 \%$. The Pearson correlation of the exon-survival associations between the training and validation data sets was $76.6 \%$.

\section{Validation}

The $R^{2}$ is the percentage of the variation of the observations explained by the exon-based, gene-centric approach. Simply put, the $R^{2}$ is an indicator of the correlation between exon expression and patient survival, adjusting for therapy, ethnicity, gender, among all terms accounted for in our model). The median $\mathrm{R}^{2}$ in the training and validation data sets were $75.7 \%$ and $63.4 \%$ for the multi- and single-exon genes significantly associated with survival. The relative difference in $R^{2}$ between the training and validation data sets was $16.2 \%$. The small drop in median $\mathrm{R}^{2}$ between the training and validating data set is a first, global indicator of the similar exon-survival relationship identified in both independent data sets. A difference between training and validating data is expected due to simple sampling effects such as between-subject variation.
Additional insight into the validation of associations detected in the training data sets was gained from the study of the correlation of the exons-survival association (e.g. estimated solution or slope) between training and validation data sets. For the multi- and single-exon genes significantly associated with survival, the median Pearson and Spearman correlations of the exon-survival associations between the training and validation data sets were $89.7 \%$ and $85.9 \%$, respectively. The high correlation of the exon-survival associations relative to the drop in $\mathrm{R}^{2}$ model fit between training and validation data sets suggests that the exon associations with survival detected are more consistent or have lower noise than the other model terms including race, gender and therapy.

\section{Conclusions}

In conclusion, AEU is a complex process and, thus, the detection and characterization of AEU associated with survival is challenging. The hierarchical model developed in this study allowed the simultaneous detection of differential expression of exons within a gene and differentially expressed genes associated with survival. From a total of 25,403 genes investigated, 2,477 multi-exon and 13 single exon genes were associated with GBM. Most of the significant genes detected by the model have been previously associated to GBM (27.78\%) or other types of cancer (36.11\%). This suggests that differential expression associated with AEU could be used as biomarkers 
for GBM and potentially other cancers. The AEU events detected for several genes (Egf, Herc2, Gpr98 and Anapc1) were consistent with AS models in AceView.

The approach used to identify alternative exon usage and gene expression associated with survival adjusted for race, gender, and therapy differences among the patients analyzed. Thus, prognostic biomarkers of glioblastoma survival were identified. Stratified analyses of the patients by age, race, therapy, and gender or evaluation of potential interactions between exons and clinical factors could uncover predictive biomarkers and offer additional insights into the alternative exon usage associations that can lead to more personalized treatments and predictive tools.

Extensions to the hierarchical model proposed in this study to identify AEU can be considered. First, the model can incorporate information of the mapping of the exons to the gene. In addition, the distance between the exons can be accommodated on the variancecovariance matrix. This would allow modeling of potentially higher dependencies between proximal exons relative to distant exons. Second, the model can incorporate information on different splicing scenarios [2]. The hierarchical model can be applied to other cancer types and to indicators other than survival.

In this study, the vast majority of the exons within a gene mapped to one strand and few exons mapped to the other strand. Thus, AEU was studied among the exons that mapped to the most frequent strand. When sufficient information on both strands within a gene is available, our model allows the consideration of information across strands. This model would allow the study of sense-antisense gene overlap and its impact on AS and regulation of gene expression following the work of Sorana Morrissy et al [90]. Their work suggested an antisense transcription-mediated mechanism of splicing regulation in human cells.

A simple yet comprehensive analytical strategy for in silico identification of survival-associated alternative exon usage and general gene expression was demonstrated. The findings from this strategy and stringent biological and statistical thresholds were validated on an independent group of patients. Our approach can be used as a first step in the identification of cancer molecular biomarkers. A subsequent step is the experimental validation of the identified alternative exon usage and patterns of association between exons series or cassettes and survival. Experimental confirmation can be obtained from exon expression studies of the proliferation and survival of glioblastoma cell lines [91] or from studies of primary glioblastoma sphere cultures (gliomaspheres), an established in vitro model for cancer stem cell expansion [92]. Furthermore, the proposed analytical strategy can be applied to next-generation sequencing data, allowing a thorough investigation of the expression pattern associated with cancer survival and other complex phenotypes.

Further validation of alternative exon usage biomarkers can be carried out using Reverse Transcriptasequantitative Polymerase Chain Reaction (RT-qPCR) assays or RNA-Seq technologies as new samples become available. Confirmation of results using RNA-Seq offers various advantages. Unlike exon arrays that require probe design and annotations, RNA-Seq can detect both known and previously unreported alternative splicing events and yet to be annotated transcripts. RNA-Seq has substantially better coverage for differentially expressed genes compared to arrays. The enhanced exon coverage and increased sensitivity to detect alternative splicing sites and differentially expressed exons constitutes a robust tool that can substantially enhance the understanding of alternative exon usage associated with complex phenotypes. The clinical benefit of alternative exon usage and associated exon cassettes or transcripts will be most valuable in cases when these biomarkers provide a significant improvement in the precision to predict survival over routinely available clinical tests and overall gene expression-based biomarkers. As a result, the impact of the superior biomarkers will likely be greatest in diseases with short average post-diagnostic survival such as glioblastoma multiforme. Likewise, alternative exon usage-based biomarkers have the potential to be helpful to predict phenotypes not accurately predicted by general gene-expression profiles. For several cancer types the recurrence of metastasis is the most compelling assessment of the efficacy of therapy. In these cases, accurate and replicable exon-based prognostic tools offer the most advantage and can complement available clinical tests.

\section{Additional files}

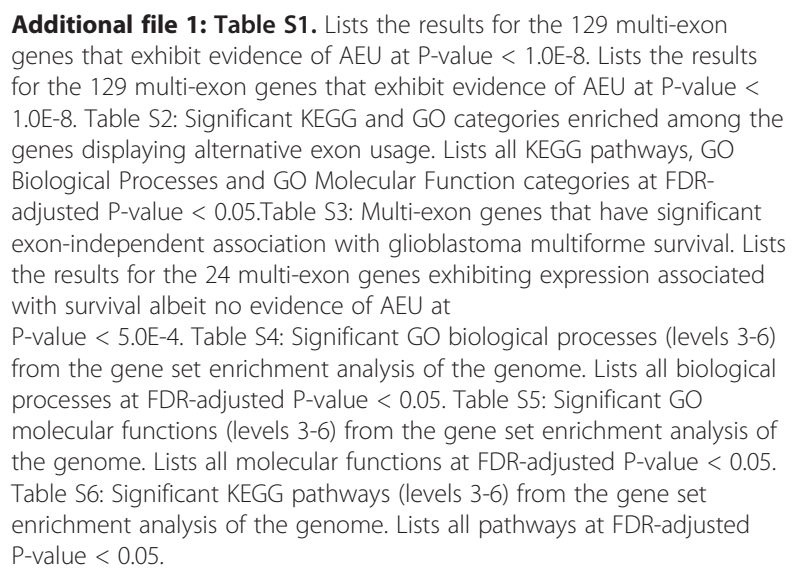

Additional file 2: Figure S1. Anapc1 exon expression, moving average, and alternative splicing models. Depicts the alternative exon expression, moving average and alternative splicing models for anaphase promoting 
complex subunit 1. Figure S2. Herc2 exon expression, moving average, and alternative splicing models. Depicts the alternative exon expression, moving average and alternative splicing models for HECT domain and RLD domain containing E3 ubiquitin protein ligase 2.

\section{Competing interests}

The authors declare that they have no competing interests.

\section{Authors' contributions}

AS obtained the exon expression data set, compiled information, performed the statistical analysis contributed to the interpretation of results, and drafted the manuscript. NVLS developed the clinical classifications, developed statistical routines, and contributed to the interpretation of the results. BRS wrote code to implement the statistical model and contributed to the manuscript. KRD contributed with the analysis. SRZ obtained funding for the study, participated in its conception, coordination, interpretation of results, and helped write the manuscript. All authors have read and approved the final version of this manuscript.

\section{Acknowledgements}

The support of NCl (Grant Number: 1R03CA143975), NIH/NIDA (Grant Numbers: R21DA027548 and P30DA018310), TCGA Data Access Committee project \#1347, and Biosciences Department COMSATS Institute of Information Technology, and the reviewer's suggestions are greatly appreciated.

\section{Author details}

Department of Animal Sciences, University of Illinois Urbana-Champaign, Urbana, IL, USA. ${ }^{2}$ Department of Statistics, University of Illinois Urbana-Champaign, Urbana, IL, USA. ${ }^{3}$ Institute of Genomic Biology, University of Illinois Urbana-Champaign, Urbana, IL, USA.

Received: 6 July 2012 Accepted: 27 November 2012

Published: 4 December 2012

\section{References}

1. Barash Y, Blencowe BJ, Frey BJ: Model-based detection of alternative splicing signals. Bioinformatics 2010, 26(12):i325-i333.

2. Laderas TG, Walter NA, Mooney M, Vartanian K, Darakjian P, Buck K, Harrington CA, Belknap J, Hitzemann R, McWeeney SK: Computational detection of alternative exon usage. Front Neurosci 2011, 5:69.

3. Sakabe NJ, Vibranovski MD, de Souza SJ: A bioinformatics analysis of alternative exon usage in human genes coding for extracellular matrix proteins. Genet Mol Res 2004, 3(4):532-544.

4. Johnson JM, Castle J, Garrett-Engele P, Kan Z, Loerch PM, Armour CD, Santos R, Schadt EE, Stoughton R, Shoemaker DD: Genome-wide survey of human alternative pre-mRNA splicing with exon junction microarrays. Science 2003, 302(5653):2141-2144.

5. Pal S, Gupta R, Davuluri RV: Alternative transcription and alternative splicing in cancer. Pharmacol Ther 2012, 136(3):283-294.

6. Ramskold D, Wang ET, Burge CB, Sandberg R: An abundance of ubiquitously expressed genes revealed by tissue transcriptome sequence data. PLoS Comput Biol 2009, 5(12):e1000598.

7. Yeo G, Holste D, Kreiman G, Burge CB: Variation in alternative splicing across human tissues. Genome Biol 2004, 5(10):R74.

8. Cheung HC, Baggerly KA, Tsavachidis S, Bachinski LL, Neubauer VL, Nixon TJ, Aldape KD, Cote GJ, Krahe R: Global analysis of aberrant pre-mRNA splicing in glioblastoma using exon expression arrays. BMC Genomics 2008, 9:216.

9. Serao NV, Delfino KR, Southey BR, Beever JE, Rodriguez-Zas SL: Cell cycle and aging, morphogenesis, and response to stimuli genes are individualized biomarkers of glioblastoma progression and survival. BMC Med Genomics 2011, 4:49.

10. Delfino KR, Serao NV, Southey BR, Rodriguez-Zas SL: Therapy-, gender- and race-specific microRNA markers, target genes and networks related to glioblastoma recurrence and survival. CANCER GENOMICS PROTEOMICS 2011, 8(4):173-183.

11. Lo HW, Zhu H, Cao X, Aldrich A, Ali-Osman F: A novel splice variant of GLI1 that promotes glioblastoma cell migration and invasion. Cancer Res 2009, 69(17):6790-6798.
12. Johnson DR, O'Neill BP: Glioblastoma survival in the United States before and during the temozolomide era. J Neurooncol 2012, 107(2):359-364.

13. Krex D, Klink B, Hartmann C, von Deimling A, Pietsch T, Simon M, Sabel M, Steinbach JP, Heese O, Reifenberger G, Weller M, Schackert G, German Glioma Network: Long-term survival with glioblastoma multiforme. Brain 2007, 130(Pt 10):2596-2606.

14. Lamborn KR, Chang SM, Prados MD: Prognostic factors for survival of patients with glioblastoma: recursive partitioning analysis. Neuro Oncol 2004, 6(3):227-235.

15. Su WL, Modrek B, GuhaThakurta D, Edwards S, Shah JK, Kulkarni AV, Russell A, Schadt EE, Johnson JM, Castle JC: Exon and junction microarrays detect widespread mouse strain- and sex-bias expression differences. BMC Genomics 2008, 9:273.

16. Purdom E, Simpson KM, Robinson MD, Conboy JG, Lapuk AV, Speed TP: FIRMA: a method for detection of alternative splicing from exon array data. Bioinformatics 2008, 24(15):1707-1714.

17. Zheng H, Hang X, Zhu J, Qian M, Qu W, Zhang C, Deng M: REMAS: a new regression model to identify alternative splicing events from exon array data. BMC Bioinforma 2009, 10(Suppl 1):S18.

18. Cline MS, Blume J, Cawley S, Clark TA, Hu JS, Lu G, Salomonis N, Wang H, Williams A: ANOSVA: a statistical method for detecting splice variation from expression data. Bioinformatics 2005, 21(Suppl 1):i107-i115.

19. Maronna RA, Martin RD, Yohai VJ: Times Series, in Robust Statistics: Theory and Methods. Ltd, Chichester, UK: J. Wiley \& Sons; 2006.

20. Klipper-Aurbach Y, Wasserman M, Braunspiegel-Weintrob N, Borstein D, Peleg S, Assa S, Karp M, Benjamini Y, Hochberg Y, Laron Z: Mathematical formulae for the prediction of the residual beta cell function during the first two years of disease in children and adolescents with insulindependent diabetes mellitus. Med Hypotheses 1995, 45(5):486-490.

21. Ji H, Wong WH: TileMap: create chromosomal map of tiling array hybridizations. Bioinformatics 2005, 21(18):3629-3636.

22. da Huang W, Sherman BT, Lempicki RA: Bioinformatics enrichment tools: paths toward the comprehensive functional analysis of large gene lists. Nucleic Acids Res 2009, 37(1):1-13.

23. da Huang W, Sherman BT, Lempicki RA: Systematic and integrative analysis of large gene lists using DAVID bioinformatics resources. Nat Protoc 2009, 4(1):44-57.

24. Subramanian A, Tamayo P, Mootha VK, Mukherjee S, Ebert BL, Gillette MA, Paulovich A, Pomeroy SL, Golub TR, Lander ES, Mesirov JP: Gene set enrichment analysis: a knowledge-based approach for interpreting genome-wide expression profiles. Proc Natl Acad Sci U S A 2005, 102 (43):15545-15550

25. Medina I, Carbonell J, Pulido L, Madeira SC, Goetz S, Conesa A, Tarraga J, Pascual-Montano A, Nogales-Cadenas R, Santoyo J, Garcia F, Marba M, Montaner D, Dopazo J: Babelomics: an integrative platform for the analysis of transcriptomics, proteomics and genomic data with advanced functional profiling. Nucleic Acids Res 2010, 38(Web Server issue): W210-W213.

26. Olson KM, Vanraden PM, Tooker ME, Cooper TA: Differences among methods to validate genomic evaluations for dairy cattle. J Dairy SC 2011, 94(5):2613-2620.

27. Marko NF, Toms SA, Barnett GH, Weil R: Genomic expression patterns distinguish long-term from short-term glioblastoma survivors: a preliminary feasibility study. Genomics 2008, 91(5):395-406.

28. Balakrishnan A, Bleeker FE, Lamba S, Rodolfo M, Daniotti M, Scarpa A, van Tilborg AA, Leenstra S, Zanon C, Bardelli A: Novel somatic and germline mutations in cancer candidate genes in glioblastoma, melanoma, and pancreatic carcinoma. Cancer Res 2007, 67(8):3545-3550.

29. Gewandter JS, Bambara RA, O'Reilly MA: The RNA surveillance protein SMG1 activates $p 53$ in response to DNA double-strand breaks but not exogenously oxidized mRNA. Cell Cycle 2011, 10(15):2561-2567.

30. Donner K, Sandbacka M, Lehtokari VL, Wallgren-Pettersson C, Pelin K Complete genomic structure of the human nebulin gene and identification of alternatively spliced transcripts. Eur J Hum Genet 2004, 12(9):744-751.

31. Difilippantonio S, Chen Y, Pietas A, Schluns K, Pacyna-Gengelbach M, Deutschmann N, Padilla-Nash HM, Ried T, Petersen I: Gene expression profiles in human non-small and small-cell lung cancers. Eur $J$ Cancer 2003, 39(13):1936-1947. 
32. Ma Y, Yuan RQ, Fan S, Hu C, Goldberg ID, Laterra JJ, Rosen EM: Identification of genes that modulate sensitivity of U373MG glioblastoma cells to cis-platinum. Anticancer Drugs 2006, 17(7):733-751.

33. Korshunov A, Sycheva R, Golanov A: Genetically distinct and clinically relevant subtypes of glioblastoma defined by array-based comparative genomic hybridization (array-CGH). Acta Neuropathol 2006, 111(5):465-474.

34. Dittrich B, Buiting K, Korn B, Rickard S, Buxton J, Saitoh S, Nicholls RD, Poustka A, Winterpacht A, Zabel B, Horsthemke B: Imprint switching on human chromosome 15 may involve alternative transcripts of the SNRPN gene. Nat Genet 1996, 14(2):163-170.

35. Moreno MJ, Ball M, Andrade MF, McDermid A, Stanimirovic DB: Insulin-like growth factor binding protein-4 (IGFBP-4) is a novel anti-angiogenic and anti-tumorigenic mediator secreted by dibutyryl cyclic AMP (dB-cAMP)differentiated glioblastoma cells. Glia 2006, 53(8):845-857.

36. 't Hoen PA, Hirsch M, de Meijer EJ, de Menezes RX, van Ommen GJ, den Dunnen JT: mRNA degradation controls differentiation state-dependent differences in transcript and splice variant abundance. Nucleic Acids Res 2011, 39(2):556-566

37. Hodzic D, Kong C, Wainszelbaum MJ, Charron AJ, Su X, Stahl PD: TBC1D3, a hominoid oncoprotein, is encoded by a cluster of paralogues located on chromosome 17q12. Genomics 2006, 88(6):731-736.

38. He ML, Chen Y, Chen Q, He Y, Zhao J, Wang J, Yang H, Kung HF: Multiple gene dysfunctions lead to high cancer-susceptibility: evidences from a whole-exome sequencing study. Am J Cancer Res 2011, 1(4):562-573.

39. Gamsiz ED, Ouyang Q, Schmidt M, Nagpal S, Morrow EM: Genome-wide transcriptome analysis in murine neural retina using high-throughput RNA sequencing. Genomics 2012, 99(1):44-51.

40. Venables JP, Klinck R, Bramard A, Inkel L, Dufresne-Martin G, Koh C, GervaisBird J, Lapointe E, Froehlich U, Durand M, Gendron D, Brosseau JP, Thibault P, Lucier JF, Tremblay K, Prinos P, Wellinger RJ, Chabot B, Rancourt C, Elela SA: Identification of alternative splicing markers for breast cancer. Cancer Res 2008, 68(22):9525-9531.

41. Vandepoele K, Andries V, Van Roy N, Staes K, Vandesompele J, Laureys G, De Smet E, Berx G, Speleman F, van Roy F: A constitutional translocation t $(1 ; 17)(\mathrm{p} 36.2 ; \mathrm{q} 11.2)$ in a neuroblastoma patient disrupts the human NBPF1 and ACCN1 genes. PLoS One 2008, 3(5):e2207.

42. Das B, Cash MN, Hand AR, Shivazad A, Culp DJ: Expression of Muc19/Smgc gene products during murine sublingual gland development: cytodifferentiation and maturation of salivary mucous cells. J Histochem Cytochem 2009, 57(4):383-396.

43. Kim JH, Park BL, Pasaje CF, Kim Y, Bae JS, Park JS, Uh ST, Kim YH, Kim MK Choi IS, Cho SH, Choi BW, Koh I, Park CS, Shin HD: Contribution of the OBSCN Nonsynonymous Variants to Aspirin Exacerbated Respiratory Disease Susceptibility in Korean Population. DNA Cell Biol 2012, 31(6):1001-1009.

44. Dong H, Luo L, Hong S, Siu H, Xiao Y, Jin L, Chen R, Xiong M: Integrated analysis of mutations, miRNA and mRNA expression in glioblastoma. BMC Syst Biol 2010, 4:163

45. Boutz PL, Stoilov P, Li Q, Lin CH, Chawla G, Ostrow K, Shiue L, Ares M Jr, Black DL: A post-transcriptional regulatory switch in polypyrimidine tractbinding proteins reprograms alternative splicing in developing neurons. Genes Dev 2007, 21(13):1636-1652.

46. Kita Y, Mimori K, Tanaka F, Matsumoto T, Haraguchi N, Ishikawa K, Matsuzaki S, Fukuyoshi Y, Inoue H, Natsugoe S, Aikou T, Mori M: Clinical significance of LAMB3 and COL7A1 mRNA in esophageal squamous cell carcinoma. Eur J Surg Oncol 2009, 35(1):52-58.

47. Wessagowit V, Nalla VK, Rogan PK, McGrath JA: Normal and abnormal mechanisms of gene splicing and relevance to inherited skin diseases. J Dermatol Sci 2005, 40(2):73-84.

48. Dalgliesh GL, Furge K, Greenman C, Chen L, Bignell G, Butler A, Davies H, Edkins S, Hardy C, Latimer C, Teague J, Andrews J, Barthorpe S, Beare D, Buck G, Campbell PJ, Forbes S, Jia M, Jones D, Knott H, Kok CY, Lau KW, Leroy C, Lin ML, McBride DJ, Maddison M, Maguire S, McLay K, Menzies A, Mironenko T, Mulderrig L, Mudie L, O'Meara S, Pleasance E, Rajasingham A Shepherd R, Smith R, Stebbings L, Stephens P, Tang G, Tarpey PS, Turrell K, Dykema KJ, Khoo SK, Petillo D, Wondergem B, Anema J, Kahnoski RJ, Teh $B T$, Stratton MR, Futreal PA: Systematic sequencing of renal carcinoma reveals inactivation of histone modifying genes. Nature 2010, 463(7279):360-363.
49. Fehlbaum-Beurdeley P, Jarrige-Le Prado AC, Pallares D, Carriere J, Guihal C, Soucaille C, Rouet F, Drouin D, Sol O, Jordan H, Wu D, Lei L, Einstein B, Schweighoffer F, Bracco L: Toward an Alzheimer's disease diagnosis via high-resolution blood gene expression. Alzheimers Dement 2010, 6(1):25-38.

50. Arne G, Kristiansson E, Nerman O, Kindblom LG, Ahlman H, Nilsson B, Nilsson O: Expression profiling of GIST: CD133 is associated with KIT exon 11 mutations, gastric location and poor prognosis. Int J Cancer 2011, 129(5):1149-1161.

51. Hoelzinger DB, Mariani L, Weis J, Woyke T, Berens TJ, McDonough WS, Sloan A, Coons SW, Berens ME: Gene expression profile of glioblastoma multiforme invasive phenotype points to new therapeutic targets. Neoplasia 2005, 7(1):7-16.

52. George CH, Rogers SA, Bertrand BM, Tunwell RE, Thomas NL, Steele DS, Cox EV, Pepper C, Hazeel CJ, Claycomb WC, Lai FA: Alternative splicing of ryanodine receptors modulates cardiomyocyte $\mathrm{Ca} 2+$ signaling and susceptibility to apoptosis. Circ Res 2007, 100(6):874-883.

53. Han J, Yang L, Puri RK: Analysis of target genes induced by IL-13 cytotoxin in human glioblastoma cells. J Neurooncol 2005, 72(1):35-46.

54. Misquitta-Ali CM, Cheng E, O'Hanlon D, Liu N, McGlade CJ, Tsao MS, Blencowe BJ: Global profiling and molecular characterization of alternative splicing events misregulated in lung cancer. Mol Cell Biol 2011, 31(1):138-150.

55. Gorlov IP, Byun J, Gorlova OY, Aparicio AM, Efstathiou E, Logothetis CJ: Candidate pathways and genes for prostate cancer: a meta-analysis of gene expression data. BMC Med Genomics 2009, 2:48.

56. Lemmink HH, Kluijtmans LA, Brunner HG, Schroder $\mathrm{CH}$, Knebelmann B, Jelinkova E, van Oost BA, Monnens LA, Smeets HJ: Aberrant splicing of the COL4A5 gene in patients with Alport syndrome. Hum Mol Genet 1994, 3(2):317-322.

57. van den Boom J, Wolter M, Kuick R, Misek DE, Youkilis AS, Wechsler DS, Sommer C, Reifenberger G, Hanash SM: Characterization of gene expression profiles associated with glioma progression using oligonucleotide-based microarray analysis and real-time reverse transcription-polymerase chain reaction. Am J Pathol 2003, 163(3):1033-1043.

58. Kimura T, Lueck JD, Harvey PJ, Pace SM, Ikemoto N, Casarotto MG, Dirksen RT, Dulhunty AF: Alternative splicing of RyR1 alters the efficacy of skeletal EC coupling. Cell Calcium 2009, 45(3):264-274.

59. Zhang L, Liu Y, Song F, Zheng H, Hu L, Lu H, Liu P, Hao X, Zhang W, Chen $K$ : Functional SNP in the microRNA-367 binding site in the 3 'UTR of the calcium channel ryanodine receptor gene 3 (RYR3) affects breast cancer risk and calcification. Proc Natl Acad Sci U S A 2011, 108(33):13653-13658.

60. Hochrainer K, Mayer H, Baranyi U, Binder B, Lipp J, Kroismayr R: The human HERC family of ubiquitin ligases: novel members, genomic organization, expression profiling, and evolutionary aspects. Genomics 2005, 85(2):153-164

61. Rainer J, Lelong J, Bindreither D, Mantinger C, Ploner C, Geley S, Kofler R: Research resource: transcriptional response to glucocorticoids in childhood acute lymphoblastic leukemia. Mol Endocrinol 2012, 26(1):178-193.

62. Haigis MC, Sinclair DA: Mammalian sirtuins: biological insights and disease relevance. Annu Rev Pathol 2010, 5:253-295.

63. Qamar L, Deitsch E, Patrick AN, Post MD, Spillman MA, Iwanaga R, Thorburn $A$, Ford $H L$, Behbakht $K$ : Specificity and prognostic validation of a polyclonal antibody to detect Six 1 homeoprotein in ovarian cancer. Gynecol Oncol 2012, 125(2):451-457.

64. Casazza A, Kigel B, Maione F, Capparuccia L, Kessler O, Giraudo E, Mazzone $M$, Neufeld G, Tamagnone L: Tumour growth inhibition and antimetastatic activity of a mutated furin-resistant Semaphorin $3 E$ isoform. EMBO Mol Med 2012, 4(3):234-250.

65. Jones S, Zhang $X$, Parsons DW, Lin JC, Leary RJ, Angenendt P, Mankoo P, Carter H, Kamiyama H, Jimeno A, Hong SM, Fu B, Lin MT, Calhoun ES, Kamiyama M, Walter K, Nikolskaya T, Nikolsky Y, Hartigan J, Smith DR, Hidalgo M, Leach SD, Klein AP, Jaffee EM, Goggins M, Maitra A, lacobuzioDonahue C, Eshleman JR, Kern SE, Hruban RH, Karchin R, Papadopoulos N, Parmigiani G, Vogelstein B, Velculescu VE, Kinzler KW: Core signaling pathways in human pancreatic cancers revealed by global genomic analyses. Science 2008, 321(5897):1801-1806. 
66. Francescone R, Scully S, Bentley B, Yan W, Taylor SL, Oh D, Moral L, Shao R: Glioblastoma-derived tumor cells induce vasculogenic mimicry through Flk-1 activation. J Biol Chem 2012, 287(29):24821-24831.

67. Garzon-Muvdi T, Schiapparelli P, ap Rhys C, Guerrero-Cazares H, Smith C, Kim DH, Kone L, Farber H, Lee DY, An SS, Levchenko A, Quinones-Hinojosa $A$ : Regulation of brain tumor dispersal by NKCC1 through a novel role in focal adhesion regulation. PLOS Biol 2012, 10(5):e1001320.

68. Swiatek-Machado K, Mieczkowski J, Ellert-Miklaszewska A, Swierk P, Fokt I, Szymanski S, Skora S, Szeja W, Grynkiewicz G, Lesyng B, Priebe W, Kaminska B: Novel small molecular inhibitors disrupt the JAK/STAT3 and FAK signaling pathways and exhibit a potent antitumor activity in glioma cells. Cancer Biol Ther 2012, 13(8):657-670.

69. Jiang ZQ, Gui SB, Zhang YZ: Differential gene expression by fiber-optic beadarray and pathway in adrenocorticotrophin-secreting pituitary adenomas. Chin Med J (Engl) 2010, 123(23):3455-3461.

70. Qiu X, Guo S, Wu H, Chen J, Zhou Q: Identification of Wnt pathway, uPA, PAI-1, MT1-MMP, S100A4 and CXCR4 associated with enhanced metastasis of human large cell lung cancer by DNA microarray. Minerva Med 2012, 103(3):151-164.

71. Kievit FM, Wang FY, Fang C, Mok H, Wang K, Silber JR, Ellenbogen RG, Zhang M: Doxorubicin loaded iron oxide nanoparticles overcome multidrug resistance in cancer in vitro. J Control Release 2011, 152(1):76-83.

72. Zheng M, Morgan-Lappe SE, Yang J, Bockbrader KM, Pamarthy D, Thomas $D$, Fesik SW, Sun Y: Growth inhibition and radiosensitization of glioblastoma and lung cancer cells by small interfering RNA silencing of tumor necrosis factor receptor-associated factor 2. Cancer Res 2008, 68(18):7570-7578.

73. Serra A, Haberle B, Konig IR, Kappler R, Suttorp M, Schackert HK, Roesner D, Fitze G: Rare occurrence of PHOX2b mutations in sporadic neuroblastomas. J Pediatr Hematol Oncol 2008, 30(10):728-732.

74. Lymbouridou R, Soufla G, Chatzinikola AM, Vakis A, Spandidos DA: Down-regulation of K-ras and $\mathrm{H}$-ras in human brain gliomas. Eur $\mathrm{J}$ Cancer 2009, 45(7):1294-1303.

75. Blanc V, Nariculam J, Munson P, Freeman A, Klocker H, Masters J, Williamson M: A role for class 3 semaphorins in prostate cancer. Prostate 2011, 71(6):649-658

76. Liao J, Yu L, Mei Y, Guarnera M, Shen J, Li R, Liu Z, Jiang F: Small nucleolar RNA signatures as biomarkers for non-small-cell lung cancer. Mol Cancer 2010, 9:198.

77. Klein A, Guhl E, Zollinger R, Tzeng YJ, Wessel R, Hummel M, Graessmann M, Graessmann A: Gene expression profiling: cell cycle deregulation and aneuploidy do not cause breast cancer formation in WAP-SVT/t transgenic animals. J Mol Med (Berl) 2005, 83(5):362-376.

78. Askarian-Amiri ME, Crawford J, French JD, Smart CE, Smith MA, Clark MB, Ru K, Mercer TR, Thompson ER, Lakhani SR, Vargas AC, Campbell IG, Brown MA, Dinger ME, Mattick JS: SNORD-host RNA Zfas1 is a regulator of mammary development and a potential marker for breast cancer. RNA 2011, 17(5):878-891.

79. Oudard S, Boitier E, Miccoli L, Rousset S, Dutrillaux B, Poupon MF: Gliomas are driven by glycolysis: putative roles of hexokinase, oxidative phosphorylation and mitochondrial ultrastructure. Anticancer Res 1997, 17(3C):1903-1911.

80. Clarion L, Schindler M, de Weille J, Lolmede K, Laroche-Clary A, Uro-Coste E, Robert J, Mersel M, Bakalara N: 7beta-Hydroxycholesterol-induced energy stress leads to sequential opposing signaling responses and to death of C6 glioblastoma cells. Biochem Pharmacol 2012, 83(1):37-46

81. Laurenti G, Benedetti E, D'Angelo B, Cristiano L, Cinque B, Raysi S, Alecci M, Ceru MP, Cifone MG, Galzio R, Giordano A, Cimini A: Hypoxia induces peroxisome proliferator-activated receptor alpha (PPARalpha) and lipid metabolism peroxisomal enzymes in human glioblastoma cells. J Cell Biochem 2011, 112(12):3891-3901.

82. Liu S, Yin F, Fan W, Wang S, Guo XR, Zhang JN, Tian Z, Fan M: Overexpression of BMPR-IB reduces the malignancy of glioblastoma cells by upregulation of p21 and p27Kip1. J Exp Clin Cancer Res 2012, 31(1):52.

83. Lenman A, Fowler CJ: Interaction of ligands for the peroxisome proliferator-activated receptor gamma with the endocannabinoid system. Br J Pharmacol 2007, 151(8):1343-1351.
84. Jiang $X$, Xing $H$, Kim TM, Jung $Y$, Huang W, Yang HW, Song S, Park PJ, Carroll RS, Johnson MD: Numb regulates glioma stem cell fate and growth by altering epidermal growth factor receptor and skp1-cullin-fbox ubiquitin ligase activity. Stem Cells 2012, 30(7):1313-1326.

85. Piro RM, Molineris I, Ala U, Di Cunto F: Evaluation of candidate genes from orphan FEB and GEFS+ loci by analysis of human brain gene expression atlases. PLoS One 2011, 6(8):e23149.

86. Millan JM, Aller E, Jaijo T, Blanco-Kelly F, Gimenez-Pardo A, Ayuso C: An update on the genetics of usher syndrome. J Ophthalmol 2011 2011:417217.

87. Nakayama J, Fu YH, Clark AM, Nakahara S, Hamano K, Iwasaki N, Matsui A, Arinami T, Ptacek LJ: A nonsense mutation of the MASS1 gene in a family with febrile and afebrile seizures. Ann Neurol 2002, 52(5):654-657.

88. Nagayama K, Kohno T, Sato M, Arai Y, Minna JD, Yokota J: Homozygous deletion scanning of the lung cancer genome at a $100-\mathrm{kb}$ resolution. Genes Chromosomes Cancer 2007, 46(11):1000-1010.

89. Sjostrom S, Andersson U, Liu Y, Brannstrom T, Broholm H, Johansen C, Collatz-Laier H, Henriksson R, Bondy M, Melin B: Genetic variations in EGF and EGFR and glioblastoma outcome. Neuro Oncol 2010, 12(8):815-821.

90. Morrissy AS, Griffith M, Marra MA: Extensive relationship between antisense transcription and alternative splicing in the human genome. Genome Res 2011, 21(8):1203-1212.

91. Poch E, Minambres R, Mocholi E, Ivorra C, Perez-Arago A, Guerri C, Perez-Roger I, Guasch RM: RhoE interferes with Rb inactivation and regulates the proliferation and survival of the U87 human glioblastoma cell line. Exp Cell Res 2007, 313(4):719-731.

92. Janiszewska M, Suva ML, Riggi N, Houtkooper RH, Auwerx J, Clement-Schatlo V, Radovanovic I, Rheinbay E, Provero P, Stamenkovic I: Imp2 controls oxidative phosphorylation and is crucial for preserving glioblastoma cancer stem cells. Genes Dev 2012, 26(17):1926-1944.

doi:10.1186/1755-8794-5-59

Cite this article as: Sadeque et al:: Identification and characterization of alternative exon usage linked glioblastoma multiforme survival. BMC Medical Genomics 2012 5:59.

\section{Submit your next manuscript to BioMed Central and take full advantage of:}

- Convenient online submission

- Thorough peer review

- No space constraints or color figure charges

- Immediate publication on acceptance

- Inclusion in PubMed, CAS, Scopus and Google Scholar

- Research which is freely available for redistribution 